\title{
The construction of an alternative quinoa economy: balancing solidarity, household needs, and profit in San Agustín, Bolivia
}

\author{
Andrew Ofstehage
}

Accepted: 30 January 2012/Published online: 3 May 2012

(C) Springer Science+Business Media B.V. 2012

\begin{abstract}
Quinoa farmers in San Agustín, Bolivia face the dilemma of producing for a growing international market while defending their community interests and resources, meeting their basic household needs, and making a profit. Farmers responded to a changing market in the 1970s by creating committees in defense of quinoa and farmer cooperatives to represent their interests and maximize economic returns. Today farmer cooperatives offer high, stable prices, politically represent farmers, and are major quinoa exporters, but intermediaries continue to play an important role in the local economy. Meanwhile, some farmers rebuff the national cooperatives and intermediaries in favor of a denomination of origin and closer association with local cooperatives. This article, based on 4 months of ethnographic research, explores the reasons for the continued presence of intermediaries on the market landscape and how farmers have worked to create a quinoa economy embedded with fair trade values. Farmers demand stable prices, flexible standards, provision of services, and promises of maintaining the distinctive qualities of San Agustín quinoa. They frame their trades in economic, utility, and solidarity terms to reflect their livelihood strategies, farming capabilities, and personal concepts of fair trade. Meanwhile cooperatives, development initiatives, and intermediaries each argue that their particular buying practices allow farmers to attain household goods, credit, and cash for food and economic security.
\end{abstract}

A. Ofstehage $(\square)$

Department of Anthropology, University of North Carolina at

Chapel Hill, CB \# 3115, 301 Alumni Hall, Chapel Hill,

NC 27599-3115, USA

e-mail: aofste@live.unc.edu
Keywords Quinoa - Quinua real · Bolivia · Fair trade · Intermediaries - Denomination of origin - Alternative development $\cdot$ Value

\section{A story}

After a long, bumpy drive from Uyuni, we parked the old truck in the plaza of Colcha " $K$," a small town perched on Bolivia's southern Altiplano. ${ }^{1}$ Isabella ${ }^{2}$ and her daughter slept in the cab, leaving the driver and me to sleep under the stars and atop the potatoes in the back of the truck. As dawn broke the next morning, the townspeople slowly realized that an intermediary had arrived during the night. The plaza in Colcha "K" was calm and chilly. Students were chatting as they ran to class and construction workers meandered to their worksite on the highway, but the town was still quiet. Breaking the silence was Isabella. She called out that her potatoes were barratisima! (very cheap) and her apples were riquisima! (very tasty). Since six o'clock Isabella, a quinoa middlewoman, had been setting up a small shop and was beginning her day of buying quinoa, selling goods, and catching up with old friends and family. Throughout the morning farmers came to purchase vegetables or fruit, others came to sell quinoa, and still others chose to hacer trueque (trade) quinoa for household goods. Farmers brought 5-50 pounds of quinoa to sell, just enough to trade for fresh fruits, school supplies, cancel a debt, or bring home a small amount of cash.

After purchasing 10 pounds of potatoes from Isabella a middle-aged farmer approached me out of curiosity. After patiently listening while I explained my research project,

\footnotetext{
${ }^{1}$ Colcha " $\mathrm{K}$ " is not a pseudonym; the " $\mathrm{K}$ " is used to distinguish it from Colcha, a city near to Oruro and Cochabamba.

2 All names in this paper have been replaced with pseudonyms.
} 
he succinctly outlined an emerging reality of quinoa producers in the region. Nearly all of the quinoa growing near Colcha "K," he said, had been destroyed by high winds early in the season, but at least this year the llama herds were surviving- $30 \%$ had been lost to drought the previous year. People were living off the profit from their llamas, remittances from relatives, or migrating to find work in Argentina, Chile, or the interior of Bolivia. He then turned my attention back to Isabella and argued that farmers should never sell to intermediaries because they sell the quinoa to Peruvian entrepreneurs who then pass off the Colcha " $K$ " quinoa as Peruvian quinoa-an affront to the quinoa farmers of Colcha " $\mathrm{K}$ " and to la patria (Bolivia). He blamed local farmers for being ignorant about the situation. They should defend their crop, he argued, by selling to the local farmer cooperative, not intermediaries. The local cooperative offers better prices and works for the farmers' interests. He then turned and continued home.

\section{Introduction}

Travels with and conversations about a quinoa middlewoman indicate something important about the regional quinoa economy in Los Lipez, a region in the southern Altiplano of Bolivia. Entrepreneurial intermediaries, national and regional farmer cooperatives, and a local denomination of origin (DO) initiative compete for a relatively stable quantity of quinoa by appealing to farmers' multiple and divergent interests. This Colcha " $\mathrm{K}$ " farmer makes clear that his own interest mixes a desire for raising prices with the hope of preserving the quinoa's local identity. He juxtaposes himself against his farmer neighbors who, from his perspective are apparently ignorant of the consequences of selling to intermediaries and interested only in their personal cash returns. This is one case of many in which Los Lipez quinoa farmers translate profit, household, and social interests into market decisions. In turn, these market decisions construct farmer identities.

From the perspective of San Agustín, Bolivia, a quinoaproducing town near to Colcha " $\mathrm{K}$," this paper is an analysis of the various meanings and values that farmers attribute to the three dominant market channels (i.e., national and regional cooperatives, intermediaries, and a locally based farmer's organization) and the ways that fair trade and development are negotiated through discourse and practice. Quinoa farmers in San Agustín make everyday value judgments within the context of market channels, the realities of living in an isolated community, and the environment in which they farm. I present a case of quinoa production and marketing in San Agustín to develop a nuanced understanding of how farmers, cooperatives, intermediaries, and activists construct a quinoa-trading network. Farmers use quinoa-trading networks in San Agustín to attain household goods, credit, and cash to ensure food and economic security. Farmers mobilize solidarity and group identity through unexpected alliances and rivalries that are strengthened and performed via market decisions. Finally, farmers create new political and economic realities in their tacit support of development visions, as represented by the three market channels.

In this paper I review established approaches to farmer practice and agency. Then, after outlining existing recent literature on the fragmented and fluctuating quinoa economy, I offer a case study of three competing and complimentary market channels in San Agustín in order to answer these questions: How do farmers create and manipulate market channels to meet their different household, social, and economic demands, in the absence of an effective formal fair trade framework? How do farmer cooperatives, independent intermediaries, and leaders of a denomination of origin initiative defend their buying practices as contributions to farmers' livelihoods? How does this case study challenge our assumptions of narrowly defined solidarity networks and the ability of small hold farmers to create economic change? I analyze this by taking account of the unique challenges of living in an isolated farming community, considering the multiple ways in which solidarity is framed, and observing the different ways that actors fulfill their visions of development. Ultimately, I show that farmers' ability to support or abandon buyers and to create new market channels offers them a measure of control in the market and enriches their work and trade, expressing broad moral visions of the community and nation. This analysis compliments Lyon and Moberg's call for an "ethnographically grounded examination of how fair trade operates in practice" at the nexus of global markets and local realities $(2010 \text {, p. } 15)^{3}$ as well of the work of Jaffee (2007) and Bacon et al. (2008). In this paper I prioritize the interface of multiple realities at the local level and in so doing, lay bare the potential of non-fair trade channels (e.g., private intermediaries) to create space for farmers to make viable wider visions of development.

\section{Local responses to global processes}

The price for quinoa has steadily increased due to rising international and local demand and relatively stagnant production (Valdez and Bajak 2011; Romero 2011). The "quinoa boom" has been posed as a saving grace for poor

\footnotetext{
3 The values of fair trade being: fair prices that exceed production costs, financing of social projects that benefit the community, prefinancing for goods, long-term trading partnerships, minimum criteria to ensure socially, economically, and environmentally responsible trade (www.fairtrade.net).
} 
farmers, a threat forcing Bolivian consumers to abandon quinoa for rice and quinoa milk for Coca-Cola, and a pressure forcing farmers to adopt modern industrial farming practices (Romero 2011; Valdez and Bajak 2011). These issues are not new. Anthropologists and economists have long focused on farmers' vulnerability to exploitation by intermediaries and international commodity buyers.

For example, Roseberry's examination of Latin American coffee economies went a long way to clarifying "preexisting and emergent fields of power" (1995, p. 8). Power issues go beyond the ability to negotiate a fair price and include the "occupation of space and transfer of landed property," the "position of regions within interregional trade networks," "location and development of roads, ports, and processing facilities," "mobilization and reproduction of labor," and so on (Roseberry 1995, p. 8). Roseberry's focus on regional differentiation within power relations and economic contexts represents a significant step away from monolithic views of commodity markets being controlled by buyers at the core merely extracting wealth from the periphery. However, by focusing on power relations and historical market formation in regional coffee economies he underestimates peasants' ability to affect real change in the transformation of regional economies.

Literature on farmer cooperatives highlights farmers' capability to defend their economic and political interests in the face of market liberalization and exploitive intermediaries. Mexican dairy farmers, for example, lost subsidies, received lower prices for milk, and suffered higher costs of production following the North American Free Trade Agreement and the subsequent liberalization of dairy markets. The farmers in McDonald's study responded by forming three farmer cooperatives to achieve greater economies of scale in the purchase of inputs and sale of dairy products and to exclude intermediaries from the market (1997). The three organizations' strategies and member agreements resulted in varied levels of success in increasing profit and filling sales contracts. However, some dairy farmers decided to farm independently or become wage laborers rather than become members. This difference in dairy farmers' economic strategies brings into question the exclusive importance of farmer cooperatives to the interests and capabilities of all farmers in the region. Farmers' diverse livelihood strategies and multiple economic activities necessitate something beyond or in addition to farmers' cooperatives.

Farmers' aspiration of removing intermediaries from commodity trade, as seen in McDonald's study, has largely been emphasized by fair trade activists. The Fair Trade Labeling Organization (FLO) has embraced farmer organizations, along with raising minimum commodity prices, and environmental regulations, as the foundation for farmer empowerment (www.fairtrade.net). The potential of cooperatives to achieve economies of scale, foster direct trading relationships between farmers and consumers (i.e., cut out the middleman), and support democratic principles have made them a cornerstone of fair trade (www.fairtrade.net). The outcome of fair trade markets in commodity-producing communities, however, has been mixed (see Lyon and Moberg 2010). Coffee producers in Oaxaca, Mexico, for example, found fair trade markets to be "better, but not great" (Jaffee 2007, p. 232). Jaffee's analysis reveals a host of unexpected consequences of fair trade, including reduced agricultural diversification with a concomitant intensification of coffee production, increased out-migration, and increased risk of food insecurity. $\mathrm{He}$ also addresses the issue of intermediaries. Despite the presence of farmer cooperatives that offer superior prices, Jaffee (2007) finds that itinerant coffee traders persist in Oaxaca as a "parallel" market to cooperatives.

Arce's work (2009) on fair trade coffee production in Guatemala provides a basis for understanding the standards and relationships imbedded in inter-related market channels that make up regional economies. His actor-oriented (Long 2001) analysis moves the focus of the dual activities of cooperatives and intermediaries beyond a purely oppositional perspective. In Loma Linda, a small coffee-producing town, producers are divided between various marketing and production strategies. A women's group exports made-to-order roasted coffee, but is opposed by men who fear that the initiative will distract women from household duties and work in the coffee plots. Differences in household and agricultural livelihood strategies further divide members of the coffee cooperative over the decision to market organic or conventional coffee. Other farmers in the community avoid the cooperative and women's group altogether by selling to intermediaries because of flexibility in buying practices. The divided market in Loma Linda, driven by farmers' disparate interests, challenges assumptions of the role of cooperatives, fair trade markets, and the way solidarity is framed:

The different networks operating in Loma Linda were the consequence of the fragmentation of large collective groupings and the way how solidarity frames, meanings and ideas of development were mobilized locally to distribute resources and target specific social segments within existing community groups. These paths to fair trade generate different texts in a context in which peoples' life worlds become fractured to embody a diversity of solidarity and fair trade categories (Arce 2009, pp. 1036-1037).

Arce portrays the fractured Guatemalan community as a life-sphere, a social entity in which actors are united by a similar activity (coffee farming in his case) but work towards separate modernities (Personal communication, Arce 2009). The life-sphere concept (see Arce 2009; 
Ofstehage 2011) recognizes divergent farmer interests or differences in available resources within a community. Colloredo-Mansfield's study on political and economic action in Ecuador also addresses the diversity of economic paths and actor motivations (2009). Artists, capitalists, and activists in Otavalo, Ecuador, defend their interests against outside hegemonic forces, including free trade agreements, but they also contest their values and beliefs within the community and in the local marketplace. Socio-economic entities (e.g., cooperatives and communities) cannot be assumed to have common values or interests. What is unique in the case of quinoa farmers is the rapidity with which these values and interests have been mobilized through the market and the intensity of the social relationships between market buyers and sellers. In this fluid market actors frame and reframe fair trade and solidarity in different ways and this, together with different levels of access to resources and markets, leads to divergent market choices and a near constant re-definition of what is fair and what is not.

The "discovery" of quinoa by consumers in the US and Europe has increased the market price for quinoa (increasing by $600 \%$ from 2000 to 2008 alone) and this has raised concerns of inaccessibility of quinoa for Bolivian consumers, increasing concentration of the means of quinoa production, and increased pressure on the fragile Altiplano soils where quinoa is grown. Quinoa farmer cooperatives in Bolivia have great potential to improve the economic outlook and political representation of farmers. Healy (2001), for example, uses the case of quinoa cooperatives in Bolivia to demonstrate that indigenous economic initiatives can create meaningful economic change. Central de Cooperativas Agropecuarias Operación Tierra (CECAOT), a national quinoa farmer cooperative, achieved early economic benefits for farmers.

Cáceres et al. (2007) analyze the history of quinoa farmers' cooperatives in Bolivia within the frame of fair trade. The authors reveal the historic formation of $\mathrm{CE}$ CAOT and the Asociación Nacional de Productores de Quinua (ANAPQUI), also a national quinoa farmer cooperative. The authors analyze the process of creating fair trade connections and competing with private quinoa exporters, but besides a comparative analysis of the prices offered by different market channels, the chapter largely disregards domestic markets for quinoa and, as with Healy (2001), the role of intermediaries in trade. Instead, the study focuses heavily on the relative economic returns of the various market channels without giving attention to solidarity frames and everyday considerations that farmers take into account.

Farmers' responses to global economic processes, including founding cooperatives and participating in fair trade markets, create change by increasing commodity prices, reducing input costs, openly incorporating political commitments, or challenging power relations. In light of this, I focus on a central problem: how are "solidarity frames, meanings and ideas of development," (Arce 2009, p. 1036) mobilized locally and expressed as alternative yet mutually reinforcing marketing channels. This broad issue resolves into three questions in southern Bolivia: Why do farmers continue to sell to intermediaries? How is the regional quinoa trading network constructed by quinoa cooperatives, quinoa intermediaries, and quinoa farmers? And, What are the implications of the commercialization of quinoa and the differentiated market channels? In responding to these questions I find that: economic activity occurs amid different social, economic, and household interests and values; differences and conflicts in and around market decisions are not necessarily problematic, but rather illustrative of alternative development visions; and the differences between the market channels effectively create possibilities for farmers.

The data for this paper is the product of 4 months of ethnographic research in San Agustín, Bolivia, and in markets in Oruro, Uyuni, Cochabamba, Challapata, La Paz, Sucre, and Potosí (see Fig. 1 for study area). Research utilized primarily ethnographic methods in order to address actors' meanings and understandings behind each market channel and to understand the discourse of various actors in and around the quinoa-trading network. Research was carried out under the framework of the Actor-Network Theory (Latour 2008) and the actor-oriented approach (Long 2001) with the goal of "following the thing" as suggested by Cook (2004). In the following sections I will provide general context around the production of quinoa in San Agustín before analyzing the positive and negative outcomes of the practices of farmer cooperatives as experienced by diverse groups of farmers in the region. I will then discuss two competing buyers for quinoa in San Agustín, intermediaries and a denomination of origin initiative, to demonstrate the competing economic, social, and utility claims at work in the local quinoa economy. To close, I examine the fair trade implications of the interacting market channels and analyze the relative power and weakness of the farmers and buyers in San Agustín.

\section{Quinoa production in San Agustín}

Since the 1970s, the demand for quinoa has expanded from isolated domestic markets in Peru, Bolivia, and Ecuador to become a widely traded food in Europe, the United States, Latin America, and Japan. This expansion is largely related to the nutritional qualities of quinoa (Rojas et al. 2004) that have made it a favorite of health-food consumers, especially vegetarians. Quinoa is high in protein, contains all 


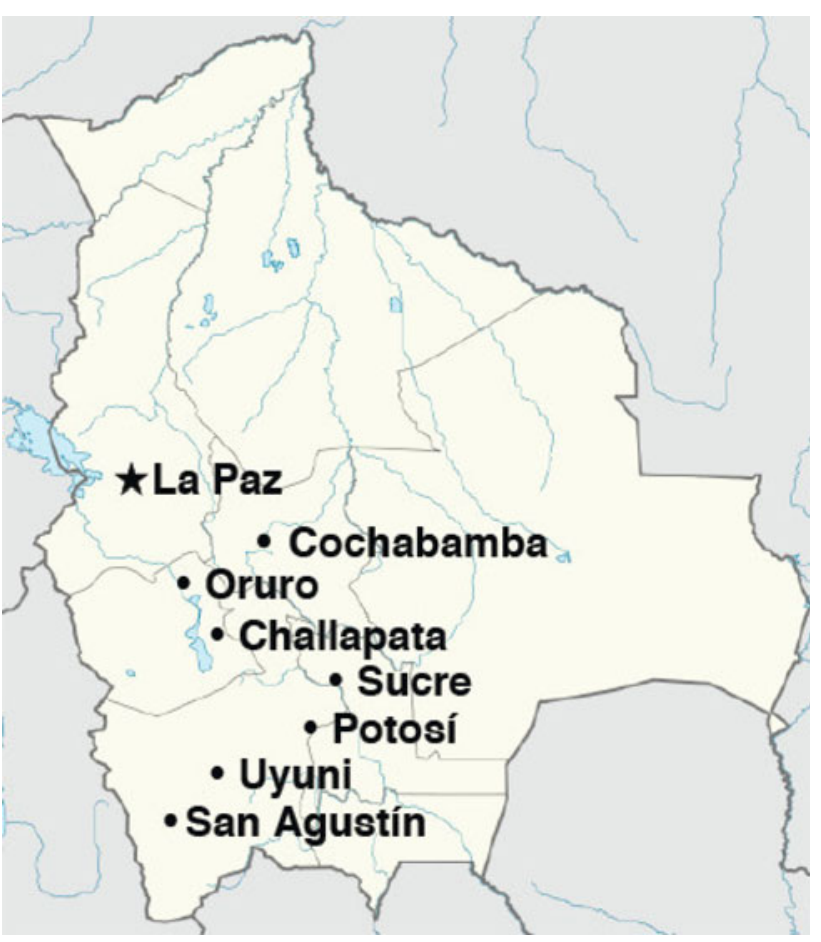

Fig. 1 Map of western Bolivia

essential amino acids, is low in fat, and is gluten-free. The price of quinoa has risen dramatically from just a few dollars per ton in the 1970 s to over $\$ 1,400$ per ton in 2009 and the market continues to fluctuate, as seen in Fig. 2. The most commonly exported type of quinoa, quinua real, is produced in the Oruro and Potosí Departments of Bolivia. Quinua dulce, a smaller grained variety, is grown mostly in the Central and Northern Altiplano of Peru and Bolivia and is generally consumed locally. ${ }^{4}$

The French non-governmental organization, Agronomes et Vétérinaires sans Frontières (AVSF) has extensively studied the impact of quinoa commercialization on production practices of farmers (Felix 2008; Quisbert and Valleur 2009). These studies have found a widespread shift from integrated farming systems, including camelids, polyculture, and fallow periods of up to 7 years, to a more mechanized system with shorter periods of fallow, reduced biodiversity, and increased use of tillage. AVSF has now implemented a program to encourage farming communities to adopt "traditional" and ecological farming techniques to conserve the land and culture of quinoa production (Felix and Villca 2009).

Other studies dispute this representation of quinoa farmers as uniformly transitioning to mechanization and question the dominance of cooperatives as primary quinoa buyers. In its review of quinoa production, the FAUTAPO

\footnotetext{
${ }^{4}$ Various types of quinoa are also produced in Chile, Ecuador, Argentina, United States, Canada, Australia, and elsewhere.
}

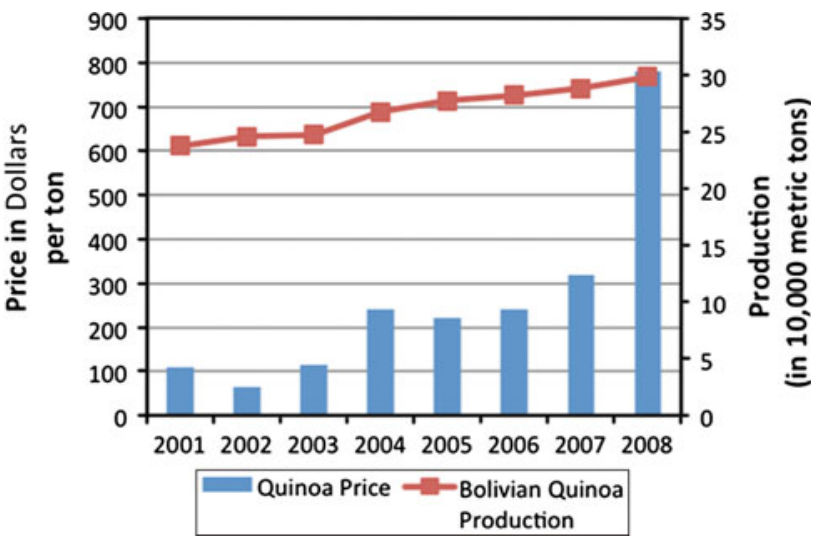

Fig. 2 Quinoa production and price (2001-2008). Elaborated by author based on figures by Laguna (2011) and the Instituto Nacional de Estadísticas de Bolivia (www.ine.gob.bo)

Foundation presents a detailed picture of how productive regions and micro-regions differ greatly in mechanization of production, average land holding, yield, and market access (Carlos-Aroni et al. 2009). Studies have found that farmers continue to sell to intermediaries despite the superior profit prices offered by cooperatives (EgoavilArce 1983; IICA 1991; Pinget and van der Heyden 1994; Ofstehage 2010; Risselborn 2011). Research also shows that the majority of consumers in Bolivia purchase quinoa through intermediary-based trade routes (Egoavil-Arce 1983; IICA 1991; Pinget and van der Heyden 1994; Borja and Soraide 2007; and Montoyo Choque 2007). Pablo Laguna (2011) documents still another fault line in the quinoa economy. In his analysis of pioneering commercial quinoa farmers, Laguna finds heterogeneous experiences and behaviors, with some farmers living in provincial towns, others conducting pluri-activity with mining, and still others using knowledge from their days as migrant farm laborers. Influenced by their different visions of modernity, farmers face a conflict in solidarity frames built around identity politics. Effectively, farmers identify as either belonging to rival regional farmer groups or as belonging to a broader coalition with a more or less unified vision for the future.

San Agustín served as an excellent site from which to observe the intermediaries' and cooperatives' competing claims for the supply of quinoa as well as the various farmer initiatives and interests at work. The Altiplano community is home to 435 quinoa-producing families, of which 254 are permanent resident families (Carlos-Aroni et al. 2009). The town and the Los Lipez region are economically dependent on quinoa production, llama raising, mining, and tourism. Quinoa is produced both on the flatlands and on the hillsides in San Agustín, to a degree insuring farmers against extreme weather. A dry season in San Agustín brings low production and drought on the 
lowlands where soil is sandy, but good harvests in the hillsides because of the greater water capacity of the hillside soil. In rainy years the hillside production is more susceptible to frosts while the flatland is likely to have sufficient water and yield well.

Farmers sow quinoa by hand in August and September, often using reciprocal family labor. During the growing season farming activities are limited to plant protectionfarmers hang compact discs from fence posts to deter birds, erect short fences to keep out rodents, and apply plant extracts and ash to prevent insect infestation. The limited amount of work necessary between planting and harvest allows many farmers to temporarily migrate al interior (to the interior of Bolivia) or to nearby Chile for work between September and March. Others remain in the region to tend to llama herds.

At harvest time, March to July, farmers manually cut the quinoa using a short, curved knife and stack it in the field to dry. After drying it for several weeks, the producers remove the stems and place the dried heads of the plant on a large mat where the seeds are separated by pounding the mass with a large wooden mallet. The separated quinoa is sieved to remove other plant material and then winnowed. Farmers winnow by pouring quinoa through the wind, allowing the wind to blow away lighter pieces of stem or chaff. The resulting product is then separated into first, second, and third-class quinoa using the same winnowing method: first-class quinoa is heaviest and falls directly down; second-class quinoa is carried slightly farther by the wind and falls further from the center of the pile, and so on. The quinoa is then stored in separate bags for each class and variety until sale. A small amount is saved for consumption and seed.

Some farmers argue that quinoa produced in San Agustín (and Los Lipez in general) is produced in a more ecological and "traditional" manner than in other quinoa-growing regions of Bolivia. Lipeño farmers (farmers from Los Lipez), for example, claimed that while producers from other regions use tractors or other mechanical aids at nearly every stage of production and harvest, Lipeña quinoa is produced with little or no mechanization. This claim is not completely accuratefarmers in other towns in Los Lipez depend on tractor power and the use of chemicals and farmers within San Agustín use different levels of mechanization - but it is a significant point in analyzing the restructuring of the market. Farmers in San Agustín and in other farming regions are not united in their pursuit of ecological and traditional production practices. In fact, a traveler I met from the Oruro Department lamented the San Agustín farmers' "stupidity" and inability to "modernize" and mechanize, saying that this backward way of producing was holding them back.

In 2002, the Fairtrade Labeling Organization (FLO) finalized a set of guidelines to certify quinoa as a fair trade commodity. The results have been mixed at best (Laguna 2008). CECAOT became a certified fair trade organization in 2007; at that time the price of quinoa at Challapata was $\$ 12.50$ per quintal $^{5}$ and the fair trade minimum price was $\$ 40$ per quintal. Needless to say, farmers and cooperatives were enthusiastic. However, demand for fair trade quinoa from consumers remained low and the cooperative ended up paying farmers fair trade prices while receiving market prices for sales. The cooperative was still recovering from this shortfall at the time of research. By 2010, the market price for quinoa had risen to $\$ 100$ per quintal while the fair trade minimum price remained the same, thereby significantly reducing the price differential between fair trade and conventional quinoa. "The problem with fair trade," according to a CECAOT agronomist, "is that it isn't fair trade." She protested the subservience of the cooperative to the FLO inspectors and standards, the small price differential, and the lack of real connection between farmers and northern buyers via fair trade certified quinoa. The cooperative is undergoing discussion with FLO to possibly raise the fair trade premium for quinoa and new standards are due to be released in 2012 (Personal correspondence, Pablo Laguna 2011), but in its current state fair trade offers little real change for farmers. ${ }^{6}$ In the absence of a working fair trade certification for quinoa, many of the core principles of FLO (fair and stable prices, linkages between farmers and consumers, democratic governance, and opportunities for economically disadvantaged producers) have in fact become endogenous to the emerging regional economy constructed by farmers, cooperatives, intermediaries, and activists.

\section{Quinoa farmers' cooperatives in San Agustín}

Quinoa markets in Los Lipez began to expand from local bartering networks into more extensive commercialized networks in the early 1970s. At the time farmers sold almost exclusively to intermediaries who procured quinoa for the Challapata market. Intermediaries in Challapata, the central quinoa market in Bolivia, brought the quinoa to markets throughout Bolivia, but primarily to Desaguadero, a small town that straddles the Peruvian border. Intermediaries had a near monopoly on the market and were often accused of using over-weight scales, under-quoting prices, and generally treating farmers unfairly. Producers responded to this exploitation by organizing farmer cooperatives and forming "committees in defense of quinoa." Community-based committees charged intermediaries with taxes and searched for market opportunities to bypass

\footnotetext{
${ }_{5}$ One quintal is 100 pounds.

${ }^{6}$ For more on the topic of fair trade quinoa, see Laguna (2008).
} 
intermediaries altogether. For example, in the 1970s a committee from the region sent out representatives to Lima to identify the destination of their quinoa and to negotiate direct selling contracts with buyers. The group succeeded in arranging a direct trading relationship with a buyer in Lima, although they were robbed of their payment on their return. ${ }^{7}$

Farmers founded two national farmer cooperatives, ANAPQUI and CECAOT, in the late 1970s and early 1980s with similar goals as the committees, specifically, to improve the price paid to farmers for quinoa, find international markets for quinoa, and reduce the power of intermediaries (Ton and Bijman 2006). Today, each national cooperative is made up of several local affiliates who operate as procurers of quinoa and as local representatives for the national cooperatives. In the following paragraphs I will outline ANAPQUI and one of its local affiliates, Centro de Desarrollo Integrado K'uichi (CEDEINKU). The make-up and procurement strategy of these two cooperatives can be taken as representative of other national and regional quinoa cooperatives in Bolivia.

The San Agustín cooperative, CEDEINKU, was founded in 1984 to procure quinoa for ANAPQUI and to represent the quinoa farmers of the Enrique Baldivieso Province. The cooperative is composed of farmer-members who have equal voting rights and led by farmer-members elected to offices. The cooperative's workers (e.g., agronomists) are generally native to the community. Approximately 400 farmers sell to the cooperative, $40 \%$ of whom are particulares (non-members), however, the quantity purchased from particulares is much lower than $40 \%$. Particulares sell conventional quinoa, or more likely organic quinoa that is uncertified, and receive a lower price. This quinoa is sold locally. Members, on the other hand, are under contract to sell $80-90 \%$ of their first-class quinoa to the organization and implement organic production practices. Organic certification prohibits the use of synthetic pesticides and fertilizers, but does not limit the use of mechanization in production. Members are also encouraged (or forced, depending on with whom one is speaking) to attend meetings and capacitaciones (extension meetings) in San Agustín and Challapata.

CEDEINKU procures quinoa from the countryside by truck when there is sufficient demand from producers and members are encouraged to bring quinoa directly to the facilities in San Agustín. At the time of research CEDEINKU offered $\$ 100^{8}$ per quintal for members and $\$ 89$ per

\footnotetext{
${ }^{7}$ Peruvian border guards accused the committee of having earned their money in the drug trade and confiscated most of the earnings. To this day, a number of farmers suspect the story is a fabrication created to allow the committee members to pocket the money.

${ }^{8}$ At the time of writing and at the time of research, one United States Dollar equals approximately seven Bolivian Bolivianos.
}

quintal for non-members. The cooperative purchases only primera (first-class) quinoa. Farmers receive a voucher for quinoa sales that can be exchanged for cash when the cooperative has sufficient funds; at times farmers are paid several months after selling their grain.

Reflecting the roots of the farmer cooperatives and the community-based committees in defense of quinoa, many cooperative workers consider their institutions to be bulwarks against intermediaries and sometimes against the farmers' own poor judgment. Maria, an agronomist with CECAOT, summarized the competition between cooperatives and intermediaries:

What the producers don't take into account is to say an intermediary goes to...today, let's say, to the community. CECAOT buys the quinoa at 700 Bolivianos per quintal and tomorrow or today an intermediary arrives and buys at 720 Bolivianos and [the farmers] know that they're buying at a little more [higher price], but what should be taken account of is, for example, the intermediary... the balance is very... overweight [that is to say, the scale undervalues the quantity of quinoa]. It [the price per quintal] is the same as when he [the farmer] is selling to CECAOT at 700 and, I don't know, a quintal and a ten more pounds is selling at $720 .^{9}$

A manager of another cooperative recounted a similar case and highlighted that farmers often know when the intermediaries are using overweight scales, but sell anyway to procure cash for particular needs. He also pointed out "dishonest" and "illegal" practice of intermediaries who, "offer higher prices, right, they bring the quinoa to Desaguadero and cross [the border to Peru] and sell [the quinoa] as Peruvian quinoa." Cooperative workers defend themselves as fair and legal alternatives to intermediaries and place themselves firmly on the side of farmers.

Quinoa farmers of San Agustín sell to CEDEINKU for several reasons. The cooperative offers high prices-at the time of research the cooperative paid members $\$ 29$ more per quintal than intermediaries. Cooperatives, although less powerful than the mining sector or the cocaleros (coca leaf growers), bring greater political power to the region. Farmers also credit cooperatives for their historic position in defending farmers' interests against intermediaries and their reputation for offering fair prices and using fair practices. CEDEINKU entered the market at a time when farmers were at the mercy of travelling, exploitive intermediaries who left little investment in the community. Many in the region, like the farmer at the beginning of this paper, support CEDEINKU and ANAPQUI out of loyalty

\footnotetext{
9 Although I have no doubt that this scenario occurs, most intermediaries offer a lower price for quinoa than cooperatives.
} 
and recognition for this. The entrance of CEDEINKU and the national quinoa cooperatives not only reduced farmers' dependence on intermediaries; it fundamentally changed the strategies of intermediaries as they sought out a kinder, gentler perception. I will return to this point in the proceeding section. The entry of cooperatives into the quinoa market opened up economic and political space in which farmers have gained a measure of political and economic control over the trade of quinoa.

Despite the economic and political benefits of selling to CEDEINKU, not all quinoa farmers affiliate. Some take issue with the rules, regulations, and inflexibility of the cooperative. Particulares often find the rules and standards implemented by the cooperative too difficult to achieve or "no vale la pena" (not worth the trouble). Although most farmers in San Agustín produce organic quinoa, many prefer not to abandon the use of synthetic pesticides completely. They argue that although pesticides are used infrequently, they can quickly eradicate infestations when needed and possibly save a crop from being lost. Others object to having their farming practices validated by another person. Finally, some quinoa farmers in San Agustín produce only a small quantity for household consumption. They sell to intermediaries when possible, but by and large membership in a cooperative is impractical due to the small and inconsistent amount of quinoa for sale.

Members also avoid CEDEINKU for its often-late payments and high quality standards. CEDEINKU generally pays a higher price than intermediaries, but payments are often made several months after a sale due to periodic capital shortfalls. This can be devastating to some farmers, especially at times when cash is in high demand. The cooperative's high quality standards represent another difficulty for members. Export-quality quinoa is first-class and organic; any quinoa that falls outside of these guidelines, including second- and third-class quinoa, can only be kept for consumption or sold to intermediaries.

A different kind of concern about selling to cooperatives harkens back to complaints about Isabella masking the identity of Colcha "K" quinoa. A small, but politically significant group of San Agustín farmers has argued for CEDEINKU's independence from ANAPQUI in order to ensure that their quinoa is sold specifically as Lipena quinoa rather than as Bolivian quinoa. From this group's perspective, the relationship between CEDEINKU and ANAPQUI is one in which the national cooperative gains access to some of the highest quality quinoa in Bolivia, provided by CEDEINKU, and then mixes that quinoa with that of other regions in order to raise the overall quality of their exports without paying a higher price for the Lipeña quinoa. The president of ANAPQUI explained that all quinoa purchased from affiliates is kept separate and exported separately, but he conceded that quinoa is exported as Bolivian, rather than specifically from Los Lipez. Farmers' interest in the independence of CEDINKU from ANAPQUI and the separation of San Agustín quinoa has also led to the creation of a denomination of origin initiative. The call for separation of Lipez quinoa is based on the physical attributes of Lipeña quinoa (it is a larger grain), the perceived social attributes of the quinoa (the "traditional" and "more-than-organic" production practices), and economic factors (the perceived greater use of manual labor in Los Lipez requires a greater labor cost of production).

A separation would allow the local cooperative to capture a greater portion of the export price by cutting out the middleperson who, odd as it seems, is the national cooperative. It would also allow San Agustín farmers to capitalize on the higher quality of Lipeña quinoa and the perceived demand for "traditionally" produced quinoa by northern consumers. Some farmers believe that their voice is not well heard within the governing structure of the national cooperative they are concerned that their lower production quantities and greater distance to processing facilities in Challapata and cooperative offices in $\mathrm{La} \mathrm{Paz}$ reduced their power within the organization. Independence from the national cooperative, some said, would allow San Agustín to self-govern. However, CEDEINKU's separation from ANAPQUI would be a difficult endeavor due to lack of water for processing, lack of relationship with Northern importers and lack of agreement on whether it should separate or not. The separation dispute indicates a conflict of solidarity frames-one group framing all Bolivian farmers together as a political project, another framing Lipeño farmers and Lipeña quinoa together in opposition to rival quinoa farmers and sub-standard quinoa.

The majority of farmers in San Agustín sell at least a portion of their quinoa to CEDEINKU and few deny the benefits that the cooperative has brought to the community, but it is clear that the cooperative is not meeting the needs of all members of the community, nor does it have a stable relationship with all farmers. Over the next two sections, I will discuss the alternatives to the cooperative to illustrate the complexity of the quinoa market in San Agustín and the different interests at play.

\section{Intermediaries as partners in development and threats to community identity}

Isabella is a single mother in her late fifties and a middlewoman. She was born in San Pedro de Quilmes, near to San Agustín, and currently lives in Uyuni-an economic center and transportation hub of the region. In the early 1980s, Isabella began periodically travelling to communities throughout Los Lipez to sell food and other goods out 
of her well-worn truck. Her travelling market allowed her to visit family and friends in the countryside and supplement her husband's wages. As the price for quinoa began to rise, she expanded her business to collect quinoa in the communities and sell unprocessed quinoa in Challapata. After divorcing her husband, Isabella took 2 years off of her intermediary business before making it her primary economic activity. She now travels once a month to collect quinoa and sell goods. She has expanded her business territory in Los Lipez and now processes quinoa before selling it in Challapata. Although Isabella's story is unique, her practices as an intermediary are generally representative of other intermediaries working in Los Lipez. ${ }^{10}$

In March 2010 I accompanied her on a trip in which she visited three communities in Los Lipez: Colcha "K," San Agustín, and Copacabana. On a typical day during the trip we would set up shop early in the morning and then wait for word to spread that an intermediary (and a gringo anthropologist) were in town. People would then come throughout the day to sell quinoa, buy goods, barter, and catch up with Isabella. Each purchase began with Isabella's appraisal of the quinoa's quality and the variety-many varieties of quinua real are produced in the region. Isabella's driver or I would then weigh the quinoa with a hand-held scale, sometimes with a farmer looking over our shoulder to confirm the weight. Once a price was agreed to, the seller took cash, canceled an existing debt, or selected goods of an equal value to take home. Farmers brought mostly second-, third-, and fourth-class quinoa and often brought just enough to exchange for goods (cleaning supplies, school supplies, cooking utensils) or a few pounds of basic foodstuffs (e.g., potatoes, noodles, rice, vegetables, fruit, etcetera).

After the buying excursion, Isabella cleaned and sorted the quinoa at her home. She sorted sacks of first- and second-class quinoa mechanically and sorted lower classes by hand to remove pebbles and seeds. After sorting the quinoa, she sold it to an intermediary at the Challapata market. From Challapata it could have gone in a number of directions, including marketplaces in Oruro, La Paz, or Cochabamba or quinoa-processing companies in La Paz. Most likely, her quinoa was purchased by a mayorista (large-scale intermediary) who brought the quinoa to markets in La Paz and Copacabana before taking the remainder at Desaguadero, at which point it would be sold to a Peruvian intermediary.

The quinoa sold to Isabella was distinct from that sold to cooperatives in quality and quantity. Isabella purchases

\footnotetext{
10 The practices of intermediaries working in Los Lipez are similar, but not representative of quinoa intermediaries working in other areas of Bolivia. The distance to markets and inadequacy of transportation make the market context in Los Lipez fairly unique.
}

conventional quinoa, thereby opening up a market channel to farmers who are not associated with CEDEINKU and are not organic-certified. She also purchases all grades of quinoa, in contrast to the cooperatives that purchase only first-class quinoa. She does this for two reasons. First, the availability of high-quality quinoa in this region is very low due to the prominence of cooperatives and this leaves her with little choice but to lower her standards. Second, Isabella hopes that her willingness to purchase low-quality quinoa will endear her to the farmers and perhaps earn her a good reputation. Isabella also differs from cooperatives in the quantity of quinoa purchased - cooperatives will rarely purchase quinoa is quantities lower than 100 pounds, but Isabella purchases any quantity.

The services that Isabella provides and her flexible standards are intended to create a reputation as an honest, trustworthy, and indispensible middlewoman. These strategies are representative of the practices of other intermediaries working in the area, though there is certainly not a single way of doing business. ${ }^{11}$ Itinerant quinoa traders improve economic and food security by bringing relatively cheap goods to isolated towns with little access to marketplaces. Staple foods in San Agustín are often twice the price of the same foods in Uyuni and fresh fruit is virtually unavailable-Isabella and other traders sell food at Uyuni market prices and provide a variety of fruit. ${ }^{12}$ They also improve the resilience of the local economy by providing easy access to cash and sometimes providing credit. Together with intermediaries' ability to purchase conventional, low-quality, and low-quantity quinoa, the services that they provide can make them indispensible to a remote farming community.

The relationship between farmer and intermediary is not strictly utilitarian. In his analysis of fair trade coffee in Mexico, Jaffee (2007, p. 77) recognizes that some intermediaries are mistrusted outsiders, but that others serve a "vital function to the remote communities." However, intermediaries in San Agustín act not only as functionally necessary, but also as community members and kin. Middlemen and women primarily compete with each other through the strength of their reputation and Isabella has cultivated her relationship with farmers since she began buying quinoa and selling. She is known to keep honest scales (not overweight), offer decent prices, and purchase absolutely any quality of quinoa. She also spends time in the field catching up with friends and family and

\footnotetext{
11 Another intermediary in the area commented that he doesn't barter or provide credit. As he said, "Se viene, se vende, se va." (One comes, one sells, one leaves.) Intermediaries are less likely to provide services in quinoa-producing regions where farmers have greater access to marketplaces and banks.

12 They are able to provide goods at Uyuni prices by purchasing at Challapata, a more vibrant and centrally located market.
} 
re-enforcing the perception that she belongs in the community. She has even made efforts to learn Quechua to reach out to non-Spanish speaking farmers. Her relationship with farmers does not guarantee a sale, but it does open the door for business. Farmers and intermediaries mutually support each other through their market transactions and often tight-knit social interactions. They build a channel that connects farmers to cash and goods, urban consumers to relatively cheap quinoa, while connecting families in and out of the region through informal gossip and passing of messages.

Of course, not all farmers in San Agustín value the work of intermediaries. Like the farmer in Colcha "K," some refrain from selling to intermediaries because of concerns that quinoa would lose its Los Lipez identity. Other farmers do not sell to intermediaries due to lack of trust. Although Isabella has carefully manicured her reputation in the community to create a strong relationship with farmers, some intermediaries confirm the stereotype of an exploitive coyote that uses faulty balances, quotes low prices, and capitalizes on marginalized farmers. Regardless of Isabella's actions, some farmers see her as an outsider who threatens their reputation and threatens the strength of the local and national cooperative. Here again, the dispute between Isabella's patrons and her detractors is a conflict of solidarity frames. For some, she has performed her role as local woman admirably and remains at least at the fringes of their solidarity frame, for others she and other intermediaries are imminent threats to their sovereignty and identity.

Intermediaries like Isabella provide essential services to rural communities by purchasing low-quality, low-quantity, and conventional quinoa. They also threaten the ability of cooperatives to set market prices and the ability of San Agustín farmers to create a reputation for their quinoa. After being superseded in the quinoa market by farmers cooperatives, intermediaries have found a niche in the market that is unexploited by the cooperatives and have specialized in addressing unrealized farmer needs.

\section{Founding a new model}

As noted above, some farmers advocate for CEDEINKU to independizarse (become independent) from ANAPQUI in order to completely separate their quinoa. Activists and farmers have created a denomination of origin (DO), a registered trademark to protect a geographically distinct and socially reproduced commodity, for "quinua real de Lipez." This initiative, which encourages Lipeño farmers to sell their quinoa as Lipeña and prohibits outside farmers from doing so, shares many of the characteristics of the studies by Daviron and Ponte (2005), Bowen and Zapata
(2009), and Barham (2003) — a shared way of farming, a distinct agro-ecology, and a definable territory. The DO is expected to bring economic benefits, augmentation of symbolic value, and possibly a greater political unity for the region.

DO initiatives, like fair trade initiatives and farmer cooperatives, are often presented as a strategy for farmers to improve their returns from commodity production. Daviron and Ponte (2005) suggest the use of DO labels as a means of adding value locally to coffee exports. Barham (2003) takes a similar approach in her study of French appellation d'origine contrôlée (AOC) labeling, but emphasizes the potential of geographic origin labeling to re-embed workers in a commodity in response to globalization. Place-based certification of Mexican tequila is another initiative with hopes for economic benefits, environmental protection, and cultural survival, although in practice few of these hopes were attained (Bowen and Zapata 2009). Colloredo-Mansfeld and Antrosio (2009) propose that the reputation of a place-based good, such as Otavalan handicrafts, is based on a constant re-interpretation of symbolic value which is built on performed value and can be appropriated by insiders and free-riders as any other commonly held good.

The movement towards differentiation of Lipeña quinoa is largely spearheaded by the Mancomunidad de la Gran Tierra de Lipez, a socio-political organization, and the Consorcio de Lipez, a consortium founded by the Mancomunidad. In November 2009, the Consorcio was granted a denomination of origin for quinua real produced in the region. The Consorcio intends to add value to local products and promote an alternative local economy based on the recognition of "tradition" and Lipeña identity through the promotion of products, development of new products, and the certification of products de Lipez (from Lipez). Lipeña quinoa is described by locals, or at least by supporters of this initiative, as fundamentally different from other types of quinua real because of the more traditional and ecologic production process and larger grain size. This distinction, they say, merits separation and a higher sales price to recognize the perceived consumer demand for these qualities as well as the perceived higher cost of production due to increased use of manual labor.

The DO label certifies the territorial origin of quinoa in Los Lipez and all quinoa is organically certified. The consortium purchases directly from local cooperatives, such as CEDEINKU and affiliated micro-businesses in communities throughout Los Lipez, many of them operated by women, elaborate products, such as energy bars and chocolate-covered popped quinoa. The products are currently sold in Bolivian health food stores and in a special Consorcio de Lipez shop in Uyuni that caters to tourists. The quantity certified is relatively small, but growing. 
The Consorcio supports the complete separation of Lipeña quinoa from other regions' production and therefore supports the independence of CEDEINKU from ANAPQUI. This is seen as a necessary step to segregating Lipeña quinoa from all others and is a primary goal of the Consorcio. It encourages farmers to not sell to intermediaries for the same reason-quinoa sold to intermediaries will be mixed with other types and its special quality will be lost. The farmers who are lobbying for CEDEINKU to become independent from ANAPQUI, the farmers who refuse to sell to intermediaries, and the Consorcio are not necessarily united in policy planning, but do share the opinion that quinoa from Los Lipez is special and should be treated as such.

In light of the buying strategies and services provided by cooperatives and intermediaries, the rationale for the denomination of origin appears to be primarily the maintenance and transmission of the reputation of San Agustín quinoa. San Agustín quinueros' (quinoa farmers) defense of the "traditional" and "more-than-organic" qualities of their quinoa reflects Mauss' (2002, p. 66) observation that "things sold still have a soul." Indeed farmers are protecting the "soul" of quinoa and their farming practices that are embedded in it. They are all fighting, in their own way, for the establishment and protection of a cultural commons (Colloredo-Mansfeld and Antrosio 2009; Ofstehage 2011) built around the production of Lipeña quinoa and for the framing of solidarity around it and Lipeño farmers, excluding outside farmers and quinoa.

The fate of the Consorcio is unsure due to the difficulties of competing with the cooperatives and intermediaries as well as a lack of interest from some farmers in San Agustín and, according to conversations with Pablo Laguna, a relative lack of interest in other parts of Los Lipez. As in the case of intermediaries and cooperatives, opinions are mixed regarding the denomination of origin; some farmers are deeply interested in the initiative as a means of creating an alternative economy in which local identity is valued while others are interested only insofar as they gain financial remuneration from the trade.

\section{Re-framing solidarity on the southern Altiplano}

Quinoa farmers of the 1960s and 1970s had only one market option-sell to itinerant intermediaries - and as a consequence they suffered exploitation through underpricing and underweighting. Since that time, farmers have founded new institutions to guarantee higher prices, invest locally, represent farmers politically, and offer straight deals. Today, all three market channels, shown in Fig. 3, fulfill a key role for at least some farmers and all three suffer in comparison to another option in some manner.
Cooperatives offer and maintain high quinoa prices and play an important social and political role in the farming communities, but accept only the highest quality quinoa, and some perceive the national cooperatives to be captured by the interests of rival quinoa farmers to the north. Intermediaries maintain low quality standards, offer flexible payment options, maintain close social bonds with farmers, and provide cheap, fresh food; however they offer comparatively low prices, mask the identity and distinctiveness of Lipeña quinoa, and will always remind some farmers of the exploitive intermediaries of time past. Finally, the Consorcio de Lipez buys at high prices and celebrates the special qualities of Lipeña quinoa and Lipeño farmers, but purchases only high-quality quinoa and, on top of that, some farmers are not concerned in the least with the celebration of Lipeña quinoa.

The contradictions of this economy are easily apparent. Intermediaries are neighbors and co-parents for some, but economic leaches for others. Cooperatives are both member-owned, democratic institutions and vehicles for the subjugation of Lipez farmers by their rivals. The Consortium is insignificant and redundant, but also the only real advocate for local farmers. This paradox, however, is only contradictory if one assumes that there exists a common vision of development within a community and a common solidarity frame. This research indicates that actors' visions of development shape their own economic reality. Within limits, actors are capable of performing their visions by supporting existing market channels or, as in the case of the Consorcio, creating new options. Farmers construct the fragmented San Agustín market to meet their own solidarity, household, and economic needs, but farmers frame solidarity differently and meet their household and economic needs by different means.

Burke (2010), Vásquez-León (2010), and Arce (2009) have previously challenged farmer cooperatives and fair trade initiatives as either incomplete in addressing farmers' needs, insufficiently democratic, or unable to overcome existing structural inequalities. In Bolivia, León et al. (2003) have documented how an initiative to organize a farmers' market in Oruro was largely unsuccessful because of lack of interest from farmers and the high cost and risk of transportation. Farmers' cooperatives, fair trade initiatives, and farmers' markets each have potential to create fair and constructive local economies, but none is a panacea for farmers. The situation in San Agustín is no different. The face-to-face market interactions between farmers, intermediaries, cooperatives, and activists, within the context of the Altiplano agro-ecosystem, has made available a range of services, solidarity, standards, and prices provided by the three market channels. No single buyer satisfies all farmers' interests, but all do offer something irreplaceable and therefore contribute to farmer livelihoods. 
Fig. 3 Major channels of quinoa out of San Agustín

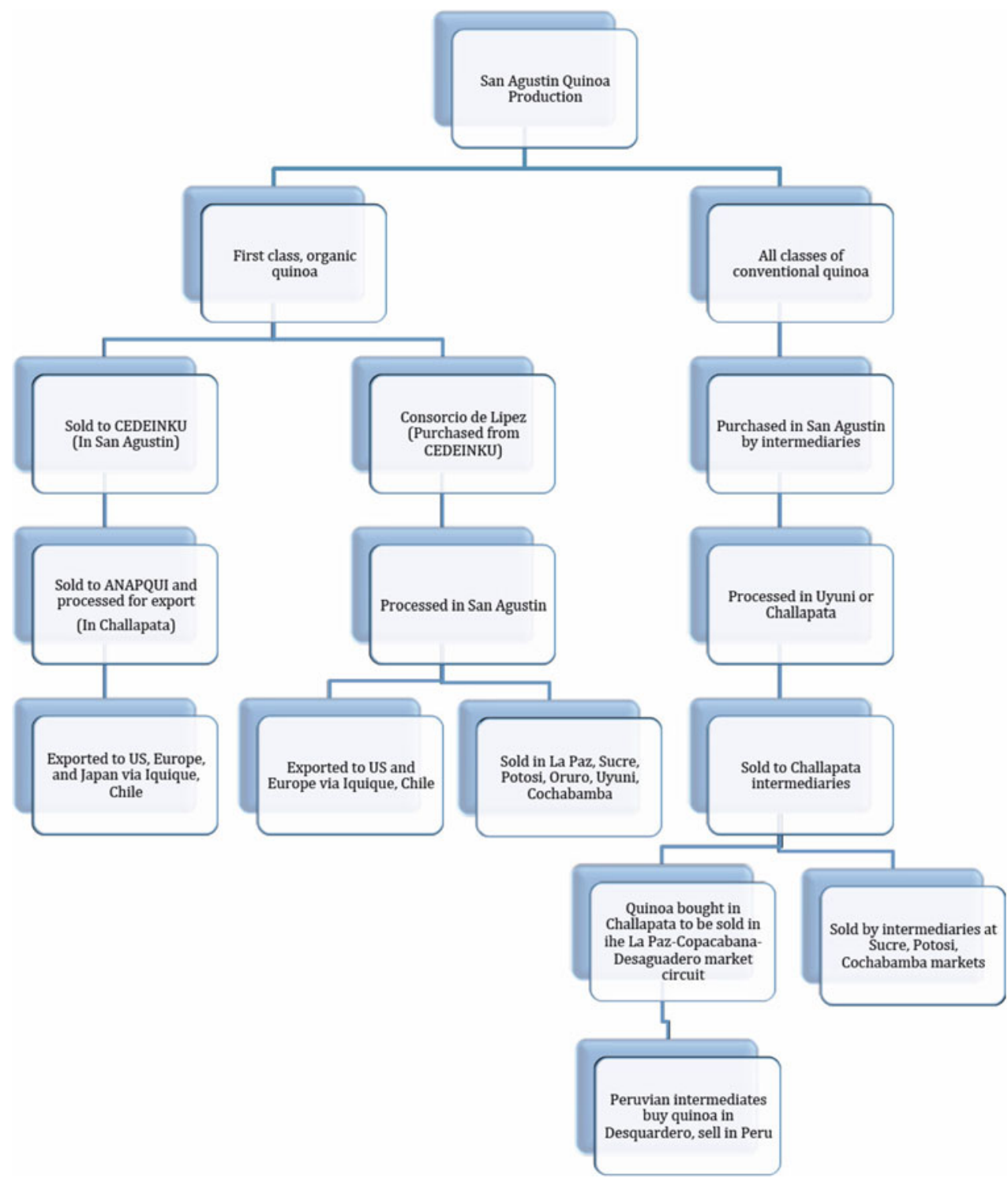

But how does this mixed economy translate to fair trade? And how is solidarity, a foundation of fair trade relationships, framed in this context? In the Bolivian Altiplano farmers are disassembling and reassembling the components of fair trade to mirror the different solidarity frames, farming strategies, economic strategies, and household priorities. Working with and against cooperatives, the Consorcio de Lipez, and local intermediaries, farmers reveal the limitations of a narrowly defined view of solidarity.

Fair trade activists stress solidarity and democratic governance in their support for farmer cooperatives, but farmers also share group identity with intermediaries and the denomination of origin initiative. In breaking down the values of fair trade-fair price, long-term trading partnerships, criteria for socially, economically, and environmentally responsible practices_one can see that farmers' demands are being met through the different quinoa buyers in San Agustín. In my numerous interviews with critical Lipez farmers the price offered by the Consortium and CEDEINKU was universally recognized as fair. Farmers forge long-term and meaningful trading partnerships with CEDEINKU, ANAPQUI, and the Consorcio. Even Isabella and other intermediaries cultivate long-term partnerships with locals by offering services and convenience. However, solidarity is lacking in some relationships in which it would be expected. San Agustín farmers do not automatically have close relations with either the national or local cooperative. Some are not members because they feel that they can better achieve their objectives through independent farming, others do not join because their way of farming does not translate well to the cooperative's strategy. Farmers who are involved with the local cooperative are split between those who feel a strong sense of regional 
solidarity (wanting to separate from ANAPQUI) and those who have a sense of solidarity with the national quinoa farmer movement (those who want to maintain the current relationship with ANAPQUI). Therefore, some farmers are closely tied to CECAOT, others are closely tied to ANAPQUI, and non-members are unaffiliated with either cooperative.

On the other hand, the movement to separate and distinguish Lipeña quinoa has fostered regional solidarity, demonstrated in joint political action in the region, prioritization of the recognition of the "superior" qualities of Lipez quinoa and Lipez farmers, and refusal or reluctance to sell un-separated Lipez quinoa. One can also see notes of solidarity in the relations between intermediaries and farmers. Isabella cultivates personal connections with farmers by purchasing low-quality quinoa at very little profit, speaking Quechua, transporting low-price goods from Uyuni, and participating in local festivals. Isabella has made herself a sufficiently local and trustworthy buyer for some farmers. The different ways that farmers frame solidarity gives value to trade routes. A stronger sense of regional solidarity, for example, may pit a farmer against ANAPQUI and against other farmer groups, while other farmers will self-identify as a Bolivian quinuero, writ large. Lastly, intermediaries are also able to foster solidarity, perhaps small 's' solidarity, by acting the part of a local.

The application of fair trade and solidarity principles to the quinoa-trading network recalls Appadurai's (1986) notion of constructed and changing perceptions of commodities. Just as things move in and out of a commodity state depending on actor's assumptions, the fairness of quinoa trade channels depends on actor perspectives. The very significance of fairness is subject to actor's priorities in commodity trade. One farmer, for example, may consider his trading relationship with CEDEINKU to be built on solidarity and an expression of his appreciation for the cooperative's work. His neighbor, however, may sell to CEDEINKU solely because the cooperative offers the highest price that day. Intermediaries are not necessarily despised or simply tolerated, but in some cases they are deeply trusted members of a community. In the absence of effective fair trade policy, farmers in San Agustín are using the various quinoa buyers to balance their economic and utility needs, create solidarity links, and defend their notions of value. The various market channels do not function merely as "parallel" and separate, as suggested by Jaffee (2007), but as inter-related sets of standards and relationships which cannot be understood without acknowledging their interactions and multiple meanings in the marketplace.

Social value and farmer agency are more than just token themes or contextual information in the San Agustín quinoa economy. Quinoa farmers create meaningful change in the regional quinoa economy through their activism and market decisions and in so doing they perform their own realities. Farmers' different social and economic values play an integral role in their interpretation of market channels, all of which fulfill the interest of certain farmers and none of which is complete. Loyalty and solidarity are performed in the quinoa marketplace of San Agustín in which cooperatives, intermediaries, and the Consorcio de Lipez justify their trades and farmers protect their interests and the interests of the community as they are perceived.

Acknowledgments I am deeply grateful for the substantial advice provided by Rudi Colloredo-Mansfeld, the guidance of Alberto Arce and Pablo Laguna, and the editing done by Amanda Johnson. I am also grateful to the four anonymous reviewers and Dr. Harvey James for their comments.

\section{References}

Appadurai, A. 1986. Introduction: Commodities and the politics of value. In The social life of things, ed. A. Appadurai, 3-63. Cambridge: Cambridge University Press.

Arce, A. 2009. Living in times of solidarity: Fair trade and the fractured life worlds of Guatemalan coffee farmers. Journal of International Development 21: 1031-1041.

Bacon, C., V.E. Mendez, S.R. Gliessman, D. Goodman, and J.A. Fox. 2008. Confronting the coffee crisis: Fair trade, sustainable livelihoods, and ecosystems in Mexico and Central America. Cambridge: MIT Press.

Barham, E. 2003. Translating terroir: The global challenge of French AOC labeling. Journal of Rural Studies 19: 127-138.

Borja, R., and D. Soraide. 2007. Estudio del Consumo de la Quinua en la Ciudad de Potosí. Oruro: Fundación AUTAPO.

Bowen, S., and A.Valenzuela Zapata. 2009. Geographical indications, terroir, and socioeconomic and ecological sustainability: The case of Tequila. Journal of Rural Studies 25: 108-119.

Burke, B. 2010. Cooperatives for "fair globalization"? Indigenous people, cooperatives, and corporate social responsibility in the Brazilian Amazon. Latin American Perspectives 37: 30-52.

Cáceres, Z., A. Carimentrand, and J. Wilkinson. 2007. Fair trade and quinoa from the southern Bolivian Altiplano. In Fair trade: The challenges of transforming globalization, ed. L. Raynolds, D. Murray, and J. Wilkinson, 180-199. London: Routledge.

Carlos-Aroni, J., M. Cayoja, and M.A. Laime. 2009. Situación Actual al 2008 de la Quinua Real en el Altiplano Sur de Bolivia. Oruro: Fundación AUTAPO.

Colloredo-Mansfeld, R. 2009. Fighting like a community: Andean civil society in an era of Indian uprisings. Chicago: University of Chicago Press.

Colloredo-Mansfeld, R., and J. Antrosio. 2009. Economic clusters or cultural commons? The limits of competition-driven development in the Ecuadorian Andes. Latin American Research Review 44: $132-157$.

Cook, I. 2004. Follow the thing: Papaya. Antipode 36(4): 642-664.

Daviron, B., and S. Ponte. 2005. The coffee paradox: Global markets, commodity trade, and the elusive promise of development. London: Zed Books.

Egoavil-Arce, M. 1983. Comercialización de la Quinua en el Altiplano Peruano. Lima: Universidad Mayor de San Marcos.

Felix, D. 2008. Culture durable du quinoa en Bolivie: Pratiques individuelles et règles communautaires. La Paz: Ruralter. 
Felix, D., and C. Villca. 2009. Quinua y Territorio. La Paz: Plural Editores.

Healy, K. 2001. Llamas, weavings, and organic chocolate: Multicultural grassroots development in the Andes and Amazon of Bolivia. South Bend, IN: University of Notre Dame Press.

IICA (Instituto Interamericano de Cooperación para la Agricultura). 1991. Estudio de Mercado y Comercialización de la Quinua Real de Bolivia. La Paz: IICA de Bolivia.

Jaffee, D. 2007. Brewing justice: Fair trade coffee, sustainability, and survival. Berkeley, CA: University of California Press.

Laguna, P. 2011. Mallas y Flujos: Acción Colectiva, Cambio Social, Quinua y Desarrollo Regional Indigena en los Andes Bolivianos. Doctoral dissertation, Wageningen University.

Laguna, P. 2008. Grano Pequeño, Mercado Pequeño, Grandes Apuestas: Estudiando los Límites de la Regulación Estatal Francesa del Comercio Justo a Partir del Caso de la Quinua. Paper Presented at the Third Colloque International sur le Commerce Equitable. Montpellier: CIRAD. 14-16 May 2008.

Latour, B. 2008. Reassembling the social: An introduction to actornetwork theory. Oxford: Oxford University Press.

León, G., H. Valdéz, and V.H. Vásquez. 2003. Mercado Kantuta: ¿Un Mercado Campesino? La Paz: PIEB.

Long, N. 2001. Development sociology: Actor perspectives. London: Routledge.

Lyon, S., and M. Moberg. 2010. Fair trade and social justice: Global ethnographies. New York: New York University Press.

Mauss, M. 2002. The gift: The form and reason for gift exchange in archaic societies. London: Routledge Classics.

McDonald, J. 1997. Privatizing the private family farmer: NAFTA and the transformation of the Mexican dairy sector. Human Organization 56(3): 321-332.

Montoyo Choque, J.C. 2007. Estimación del Consumo de la Quinua en la Ciudad de Oruro. Oruro: Fundación AUTAPO.

Ofstehage, A. 2011. Nusta Juira's gift of quinoa: Peasants, trademarks, and intermediaries in the transformation of a Bolivian commodity economy. Anthropology of Work Review 32(2): $103-114$.

Ofstehage, A. 2010. The gift of the middleman: An ethnography of quinoa trading networks in Los Lipez of Bolivia. Master's Thesis, Wageningen University.
Pinget, K., and D. van der Heyden. 1994. Estudio de Comercialización de la Quinua en el Mercado Nacional: Alternativas para las Organizaciones de Productores. Potosí: PROQUIPO.

Quisbert, J., and R. Valleur. 2009. Estudio del Impacto del Comercio Justo de la Quinua en el Altiplano Sur de Bolivia. La Paz: Agronomes et Vétérinaires sans Frontières.

Risselborn, D. 2011. Market power of middlemen: The case of quinoa in Bolivia. Master's Thesis, Stockholm School of Economics.

Romero, S. 2011. Quinoa's global success creates quandary at home. Manhattan: New York Times.

Roseberry, W. 1995. Introduction. In Coffee, society, and power in Latin America, ed. W. Roseberry, L. Gudmundson, and M. Samper Kutschbach. Baltimore: Johns Hopkins University Press.

Rojas, W., J.L. Soto, and E. Carrasco. 2004. Study on the social, environmental, and economic impacts of quinoa promotion in Bolivia. La Paz: PROINPA Foundation.

Ton, G., and J. Bijman. 2006. The role of producer organizations in the process of developing an integrated supply chain: Experiences from quinoa chain development in Bolivia. Paper presented at the 7 th international conference on management in agrifood chains and networks, Ede, The Netherlands, 31 May-2 June 2006.

Valdez, C., and F. Bajak. 2011. Quinoa's popularity boon to Bolivians. Durham, NC: The Herald Sun.

Vásquez-León, M. 2010. Free markets and fair trade, collective livelihood struggles, and the cooperative model: Two case studies from Paraguay. Latin American Perspectives 37: 53-73.

\section{Author Biography}

Andrew Ofstehage has a Bachelor's degree in agronomy from South Dakota State University and a Master's degree in management of agro-ecological knowledge and social change from Wageningen University. $\mathrm{He}$ is currently a $\mathrm{PhD}$ student in the Anthropology Department at the University of North Carolina at Chapel Hill. 